\title{
DEVELOPING CRITICAL THINKING TRHOUGH TRANSFORMATIVE PEDAGOGY
}

\author{
Mihaela VOINEA ${ }^{1}$
}

\begin{abstract}
Critical thinking tends to be seen more than a competence for adaptation. It is one of the most important meta-competences for future society. This study addresses two research questions: What kind of educational strategies are necessary for developing critical thinking skills?

How can teachers develop students' critical thinking competences?

The goal of this study: to identify the adequate strategy for developing critical thinking as a 21st century competence. This study involved a longitudinal research for a period of five years (2014-2019) and included 300 participants (students and teachers). For developing critical thinking as a meta-competence all teachers have to use the transformative pedagogical strategy in their daily practice.
\end{abstract}

Key words: critical thinking; transformative pedagogy, meta-competences.

\section{Introduction}

This article underlines the teachers' need to redefine and redesign the learning environment and competences according to new society demands and students' psychological profile. The evolution of technology, the dynamics of social life and the recent health crisis forced many teachers, parents and students to change their point of view on learning. A lot of recent research (Robinson \& Aronica, 2015; Senge, 2016; Stolovitch \& Keeps, 2017) brings strong arguments for the need to rethink school and the learning environment and develop competences for the future society. Among these future competences, critical thinking and socio-emotional skills are always mentioned. A true challenge for all educators is finding a teaching strategy to develop these future competences.

\section{Transformative Pedagogy - A Solution for a new School?}

Today, the industrial model of school tends to be replaced by an organic model of school (analogy with the organic agriculture). The industrial model is based on five assumptions, which were useful for the industrial society: children are deficient and schools fix them; the learning as an individual process takes place in student's head not in the whole person; all

${ }^{1}$ Transilvania University of Braşov, mihaela.voinea@unitbv.ro, corresponding author 
students learn in the same way; learning takes place in the classroom, not in the world; some students are smart and others are stupid (Senge, 2016). These representations regarding school were so strong that even today we find some of them in some parents' or even teachers' mentalities.

But in a global, digitized society with students who are digital natives (Prenski, 2001), who are fast information processors, multi-taskers, who enjoy gamification and whose social values hierarchy is dynamic, schools have to redefine their roles and places in students' lives. The industrial school model cannot face the new challenges concerning students' and society's demands.

A new model of school and learning is raised - an ecological model/ organic model which is centred on four principles: health, ecology, correctness, and care (Robinson \& Aronica, 2015). Health refers to students' wellbeing, ecology - the interdependence between cognitive, affective and social dimensions of human developing, correctness - stimulating each student's potential and care - the creation of optimal conditions for development. These principles are more adequate to contemporary schools and students because the evolution of technology must be accompanied by human values such as empathy, cooperation, human solidarity, responsibility, citizenship. This is not a new idea, for example Naisbitt since 1989 highlighted the links between high technology and high human reactions and Harari (2018) says the same thing in other words: we need people with strong moral values to use computers and robots. For these, a new approach to school and learning is needed based on the conception of the human being as an organism that changes and develops

Another argument for the necessity to change our mind-set on learning is offered by Mezzirow's learning theory. Mezzirow defines transformative learning as "the process by which we transform problematic reference frameworks (mentalities, mental habits, perspectives on meanings) - sets of assumptions and expectations - to make them more comprehensive, lighter, more reflexive and more capable of affective change" (Mezirow, 2014, p.168).

It is important to underline that all contemporary learning theories focus on experience (both cognitive and affective) and the power of learning to change us. The changes occur as learning outcomes are produced by positive affective relations.

For instance, Cozollino (2017) argues that today there is a need for a friendly learning environment, like a tribe, based on affection, a learning which considers the student in a holistic way, as a complete human being - with their cognitive, affective and social development.

The "Flipped Classroom" is another argument for changing the learning environment. The starting point is the experience of Salman Khan (2013) who successfully used videos on the YouTube platform to teach math to his cousin. A flipped classroom is an instructional strategy that mixes individual learning and collaborative learning within different learning contexts - in the classroom, outside the classroom, online and face to face. A recent research shows (Hu, Cai, \& Zhang, 2019) that the flipped classroom strategy is a more differentiated and personalized learning than the traditional learning and encourages students to learn in a more active way. We consider that this type of pedagogical strategy helps develop critical thinking because it engages students in an authentic, transformative learning. 
We can affirm, based on the theories presented above, that the transformative pedagogy can became a solution for a new model of learning, which is a type of learning adequate for the new generation and the future society: a learning based on individual experiences which involves the whole person in a flexible context, in classroom or in society, on line or offline, individual or together with others at a distance.

\section{Developing Critical Thinking as a Meta-competence through Transformative Pedagogy}

The concept of critical thinking can be approached through tree perspectives: philosophical, cognitive psychological and educational.

In this study we focus on the educational approach that defines critical thinking as an essential competence, which includes knowledge, skills (as decision making and problem solving, analysing different points of view) and attitudes (intellectual humility, selfconfidence, perseverance, etc.). But nowadays, critical thinking tends to be seen as more than a competence for adaptation. It is one of the most important meta-competences for the future society. The extraordinary evolution of technology that has digitized almost all dimensions of human life from work and learning to leisure has required redefinitions of competences as it was demonstrated by a lot of international education documents (Marope, 2018). For example, critical thinking was redefined from 21st century perspective not only as evaluating evidence and problem resolving, but also as a meta-cognitive competence which involves design thinking, innovation and prosocial attitudes. T. Wagner (2014) presents seven skills of innovators and critical thinking is mentioned on the first place. The Partnership for 21st Century Learning describes four competences which will be important in the future, named 4C: Critical thinking, Communication, Collaboration and Creativity.

All these perspectives underline that critical thinking is a complex a meta-competence according to Brown's (1993) opinion: learning, adapting, anticipating and creating change. Critical thinking as a meta-competence can be developed through the process of transformative learning in different contexts, not only in schools through specific contents.

\section{Research Questions, Objectives and Method}

This study addresses two research questions: What kind of educational strategies are necessary for developing critical thinking skills? How can teachers develop students' critical thinking competences?

The goal of this study was to to identify the adequate strategy for developing critical thinking as a $21^{\text {st }}$ century competence from the perspective of pre-service teachers.

The present study was conducted in a qualitative structure, embedded in a constructivistinterpretivist research paradigm because we were interested in getting a deep understanding of specific cases within a particular context.

This study involved a longitudinal research for a period of five years (2014-2019) and included a number of 300 participants, students from bachelor level (150) and master level (100) from Transilvania University, and teachers from the continuous training system who are practitioners in preschool ( 20 teachers) and primary school (30 teachers). 
Students from bachelor and master level attended the Critical thinking optional course. After completing the course, the students developed an essay on the role of critical thinking in school and contemporary society. The data were collected from participants after the end of course. Informed consent was obtained from all participants. We used the content analysis of essays.

We conducted an interview with teachers regarding teaching and learning critical thinking. We observed lessons (as assessor for exams for the teaching career) and analysed lessons plans, official curricula and teachers ' portfolios. We conducted interviews with the teachers after they had taught (self-assessments) and we recorded information regarding the following aspects of learning and teaching critical thinking according to a previously established set of criteria: teaching and learning strategy, context of learning, benefits of critical thinking.

Data analysis methods included: transcribing the interviews and observation data; interviews and document content analysis.

\section{Results}

The content analysis of the students' essays highlights that most students approach topics that are directly related to their experience and the impact of critical thinking course on their development. We found four categories that were described (benefits of critical thinking, critical thinking methods, critical thinking in society and teachers' role). We notice a difference between bachelor and master level students regarding the role of the teacher in the development of critical thinking, as you see in the following table.

The frequency of topics in students 'essay

Table 1

\begin{tabular}{|l|c|c|c|}
\hline Topics & Bachelor & Master & Total \\
\hline Formative outcomes of course & $83,33 \%$ & $82 \%$ & $82,8 \%$ \\
\hline Critical thinking methods & $77,33 \%$ & $71 \%$ & $74,8 \%$ \\
\hline Need of critical thinking in society & $68 \%$ & $64 \%$ & $66,4 \%$ \\
\hline Teachers' role & $43,33 \%$ & $54 \%$ & $47,6 \%$ \\
\hline
\end{tabular}

The students from bachelor and master level described the formative effects of the critical thinking course, which were observed in communication, self-confidence or often using multiple perspectives in decision making. Critical thinking methods are a topic often addressed in student essays. Debates, "thinking hats" or project-based learning are the most beloved methods because they produce authentic learning and create wellbeing for all participants. The teachers' role in developing critical thinking is a topic addressed especially by master degree students. A possible explication may be that at this education level students have a deep perspective on critical thinking and can see beyond immediate effects.

The qualitative analysis of essays in terms of expressions used, quality of arguments, expressiveness of examples demonstrated that the students from master degree level had a layered and nuanced understanding of critical thinking: "Critical thinking is essential in personal and social life" (O.A.) 
The frequency of benefits gained in Critical thinking course

Table 2

\begin{tabular}{|l|c|c|c|}
\hline Benefits of critical thinking & Bachelor & Master & Teachers \\
\hline Constructing and presenting reasons & $78,66 \%$ & $43 \%$ & $62 \%$ \\
\hline Assertive communication & $64 \%$ & $34 \%$ & $84 \%$ \\
\hline Cooperation & $58 \%$ & $32 \%$ & $78 \%$ \\
\hline Using multiple perspectives & $54,66 \%$ & $46 \%$ & $42 \%$ \\
\hline Personal development & $48 \%$ & $64 \%$ & $34 \%$ \\
\hline
\end{tabular}

Regarding the benefits of the critical thinking course, both students and teachers mention especially cognitive benefits such as constructing and presenting reasons and in a lesser degree, benefits in terms of attitudes and values. This is a weakness of the teaching strategies.

From the interview with the teachers, we found that teaching critical thinking is approached in a constructivist manner, which is visible in the content and methods. Many teachers (64\%) reduce critical thinking to the use of interactive methods or strategies. This is understandable because strategies are easily visible and measurable. Even if the teachers' interest in for critical thinking has risen, they focus on teaching about critical thinking and focus less on attitudes and values.

Another aspect of the critical thinking course which was analysed in the interviews with the teachers was the context/environment of learning. We found that teachers used a traditional context for teaching and learning critical thinking, in classroom but in a funny way. The teachers often use creative ways of organizing the students and the classroom space.

This is another weak point of teaching critical thinking, because the critical thinking competences are developed in any context which involves decision making, and using values and attitudes. The teachers can develop critical thinking as a meta-competence for their students if they themselves become authentic critical thinkers and use the transformative pedagogy in classroom and if they are open to change the learning context. These are the answers to our research questions.

\section{Discussion}

For developing critical thinking as a meta-competence, all teachers have to use the transformative pedagogy strategy in their daily practice.

It is not enough to just use critical thinking methods or interactive teaching strategies such as pre-cooperation learning, project-based learning and so on. It is necessary to change the context of learning (not only in the classroom) and encourage a different way of understanding the diversity of life problems. It is necessary to develop attitudes and values in any context. In school we, as teachers, have to find the balance between learning about critical thinking and engaging in critical thinking in order to become an authentic critical thinker. Critical thinking is more than a content in curriculum which involves knowledge about arguments or skills for debate. Critical thinking has to be practised every day in different contexts.

Even if critical thinking is compulsory content in the Romanian curriculum from 6th grade, it remains just a singular approach not enough to develop such a complex competence as critical thinking. Even if there are used a lot of interactive methods - debate, journal reflection, Thinking Hats, Mind Maps, Jig Saw Cooperative Classroom- critical thinking is for many teachers and students just an interesting subject matter. 
For many times, teaching critical thinking remains at superficial levels (surface learning). For the deep learning of critical thinking, a constructivist approach is necessary, which encourages learners to (re)construct their own knowledge through collaboration with other colleagues and teachers. The individual and social experience plays an important role in developing deep and nuanced thinking and feeling. This transformative pedagogical strategy can determine students to continue experimenting, reflecting and developing their skills long after the lesson has ended.

\section{References}

Brown, R. B. (1993). Meta-Competence: A Recipe for Reframing the Competence Debate. Personnel Review, 22(6), 25-36. Retrieved from http://doi.org/10.1108/ EUM0000000000814

Cozollino, L. (2017). Predarea bazată pe atasament. Cum să creezi o clasă tribal [Attachment-Based Teaching: Creating a Tribal Classroom]. Bucuresti: Trei.

Khan, S. (2013). O singură școală pentru toată lumea. Să regândim educația [The One world Schoolhouse: Education Reimagined]. București: Publica.

Harari, Y. N. (2018). 21 de lectii pentru secolul XXI [21 Lessons for the 21st Century]. lasi: Polirom.

Hu, F., Cai, X., \& Zhang, X. Y. (2019). A Flipped Classroom Designed for the Teaching of "Network Equipment Configuration and Management". Open Journal of Social Sciences, 7, 201-208. Retrieved from https://doi.org/10.4236/jss.2019.75016

Marope, M. (2018). Future competences for future generation. In Focus. Retrieved from https://ibe-infocus.org/articles/future-competences-future-generations/

Mezirow, J. (2014). O privire de ansamblu asupra învățării transformatoare [An Overview of Transformational Learning]. In K. Illeris, Teorii contemporane ale învățării. Autori de referință [Contemporary Learning Theories. Reference authors] (pp. 164-191). București: Trei.

Naisbitt, J. (1989). Megatentide. Zece noi direcții care ne schimbă viața [Mega Trends. Ten new directions that change life]. București: Politică.

Prenski, M. (2001). Digital natives, Digital immigrants. On the Horizon, 9(5). Retrieved from https://www.marcprensky.com/writing/Prensky\%20-

\%20Digital\%20Natives\%20Digital\%20Immigrants\%20-\%20Part1.pdf

Robinson, K., \& Aronica, L. (2015). Școli creative. Revoluția de la bază a învățamântului [Creative Schools: The grassroots Revolution that's transforming education]. Bucuresti: Publica.

Senge, P. (2016). Scoli care învață. A cincea disciplină aplicată în educație [Schools that Learn. A Fifth Subject Matter Applied in Education]. București: Trei.

Stolovitch, D. H. \& Keeps, J. E. (2017). Formarea prin transfomare. Dincolo de prelegeri [Transformation training. Beyond lectures]. București: Trei.

Wagner, T. (2014). Formarea inovatorilor. Cum creștem tinerii care vor schimba lumea de mâine. [Training innovators. How to raise young people who will change the world of tomorrow]. București: Trei.

***The Partnership for 21st Century Learning. Retrieved from https://www.imls.gov/assets/1/AssetManager/Bishop\%20Pre-Con\%202.pdf 